Dunamis: Jurnal Teologi dan Pendidikan Kristiani

Volume 5, Nomor 1 (Oktober 2020)

ISSN 2541-3937 (print), 2541-3945 (online)

http://www.sttintheos.ac.id/e-journal/index.php/dunamis

DOI: 10.30648/dun.v5i1.336

Submitted: 18 April 2020

Accepted: 1 September 2020

Published: 17 Oktober 2020

\title{
Pendidikan Teologi Multikultur: Sebuah Sumbangan Pete Ward
}

\author{
Stella Y.E. Pattipeilohy \\ Program Pascasarjana Universitas Kristen Duta Wacana \\ exlentyapattipeilohy@yahoo.com
}

\begin{abstract}
The task of education is to present Christ in a new way for every generation in its culture. Pete Ward compiled a theological education guide for church renewal using a Liquid Ecclesiology approach as a combination of empirical and theological methods. It is called the empirical method because it is based on a concrete church experience. One such experience is church in the context of a multicultural society. In the multicultural theological education guide, there are five elements, namely contemplation, reflexivity, construction, and expanding fragments and editing expressions. Through a dialogue between the concept of multiculural theological education with the experience in the GPIB church, a new church is presented, namely a friendly, humble, and keep on learning to the world where the church is living.
\end{abstract}

Keywords: church; Christian education; multiculturalism; public theology; ecclesiology

\begin{abstract}
Abstrak
Tugas pendidikan adalah menghadirkan Kristus dengan cara baru bagi setiap generasi di dalam kebudayaannya. Pete Ward menyusun panduan pendidikan teologi untuk pembaruan gereja dengan memakai pendekatan Liquid Ecclesiology sebagai kombinasi antara metode empiris dan teologis. Disebut metode empiris karena berbasiskan pada pengalaman menggereja yang konkret. Salah satu pengalaman itu adalah gereja di konteks masyarakat multikultural. Di dalam panduan pendidikan teologi multikultural itu terdapat lima elemen, yaitu kontemplasi (contemplation), refleksi/perenungan (reflexivity), konstruksi (construction) dan menyusun proposal dan memeriksa tindakan (expanding the fragments and editing expression). Melalui dialog antara konsep pendidikan teologi multikulural dengan pengalaman menggereja GPIB dihadirkan gereja yang baru, yaitu wajah ramah, rendah hati dan terus belajar pada dunia di mana gereja hadir.
\end{abstract}

Kata Kunci: gereja; pendidikan Kristiani; multikulturalisme; teologi public; eklesiologi 


\section{PENDAHULUAN}

Tulisan ini adalah usaha mengembangkan lebih konstruktif salah satu bab dalam buku Liquid Ecclesiology karangan Pete Ward, tentang pendidikan teologi dalam gereja. ${ }^{1}$ Perhatian Ward pada isu pendidikan tidak terlepas dari bidang keahlian teologi praktis yang digelutinya selama ini. Ia mengalami sendiri bagaimana pelayanan terhadap kaum muda (youth ministry) telah membawa dampak pada keterlibatan konkret di dalam pelayanan di tengah konteks budaya populer. Pendidikan terkait langsung dengan proses penyadaran dan perubahan karakter manusia yang membawa dampak pada transformasi diri dan transformasi sosial. Segi teologi praktis yang dimaksud Ward dan paling jelas terlihat adalah bagaimana teologi bertanggung jawab pada proses pendewasaan iman warga gereja. Tidak sekadar pola peribadatan menurut tradisi yang perlu diubah dengan kesadaran kontemporer, tetapi juga agar peribadatan tersebut membawa umat masuk ke dalam dunia yang sesungguhnya dengan seluruh dinamika persoalan dan sistem masyarakatnya yang kompleks. Kedewasaan iman akan berdampak pada keterlibatan nyata warga gereja pada prak-

\footnotetext{
${ }^{1}$ Pete Ward, Liquid Ecclesiology: The Gospel and the Church (Leiden \& Boston: Brill, 2017).
}

sis hidup di tengah dunia yang sedang berubah hari ini.

Menurut Ward, pendidikan sangat menentukan bagi terbangunnya kesadaran bahwa di hari ini konteks yang dihadapi gereja sudah berubah. Pendidikan dalam perspektif Liquid Ecclesiology menolong orang Kristen di hari ini untuk memberi perhatian pada hidup gereja dan misinya. Keberadaan gereja sendiri bukan hanya karya Roh Kudus, tetapi juga bagian dari entitas budaya, sosial dan sejarah dari masyarakatnya. Tugas pendidikan adalah menghadirkan Kristus dengan cara baru bagi setiap generasi di dalam konteks kebudayaan, sosial dan sejarahnya. ${ }^{2} \mathrm{Me}-$ lalui pekerjaan Roh Kudus, gereja dipertahankan tetap awet muda (the church young) dalam misi dan organisasi, dan kemudaannya itu diekspresikan dalam macam-macam budaya termasuk dalam budaya populer yang serba digital. Budaya sendiri bersifat cair karena kemampuannya menerima masukan dari berbagai unsur yang datang dari mana saja. Setiap hari budaya yang bersifat cair itu dibarui dan terus dibarui oleh energi kreatif (creative energy) masyarakatnya yang bersifat dinamis dan terbuka pada masukan yang

\footnotetext{
${ }^{2}$ Ibid, 200.
} 
datang itu. Hal ini berarti bahwa tidak ada data empiris dan teologis yang karena berangkat dari pengalaman empiris maka bersifat permanen atau tetap. Karena pengalaman empiris tidak pernah sama, maka teologi pun ditantang untuk membarui metodenya agar pesan Ilahi yang mau disampaikan relevan dan menjawab kebutuhan konteks.

Menurut Ward, Liquid Ecclesiology dibangun dari sebuah perspektif teologis yang asalnya tidak lain adalah sebuah paradoks, yaitu paradoks relasi antara ekspresi budaya di satu pihak dan kehadiran Yesus Kristus di pihak lain. Kata Pete Ward, "Liquid Ecclesiology has been an exercise in developing a theological perspective that addresses the central paradox of the Church. This paradox centres on the relationship between cultural expression and the presence of Jesus Christ."3 Gereja sejatinya berada dalam ketegangan di antara sisi budaya di mana ia tumbuh dan berkembang, termasuk karena budaya populer, dan kehadiran Yesus Kristus sebagai faktor utama pembentuk persekutuan yang namanya gereja. Apa yang Ward katakan ini menjadi pintu masuk untuk melihat keterkaitan idenya dengan

\footnotetext{
${ }^{3}$ Ibid.

${ }^{4}$ Ibid.
}

apa yang sekarang disebut konteks multikulturalisme. Ward hendak menegaskan bahwa Liquid Ecclesiology adalah model pengetahuan yang berbasis pada data empiris, sebagaimana berlaku pula dalam sejarah penafsiran dalam tradisi biblis dan teologis. Sebagai data empiris, maka tradisi biblis dan teologis, sekalipun berisikan narasi tentang Allah, namun karya-Nya itu hadir dalam pengalaman orang beriman yang bersifat temporer, artinya terbatas sesuai dengan daya tangkap manusia memahami kehendak Allah. Termasuk data empiris yang penting dalam percakapan ini adalah pengalaman di tengah budaya multikultural. Dalam konteks multikultur, hidup gereja dihayati sebagai karya Roh Kudus, tetapi Roh terekspresikan dalam pengalaman kebudayaan yang menjadi energi kreatif (creative energy) dari manusia. ${ }^{4}$

Sesuai dengan konteks kemajemukan budaya, maka teologi kontekstual mempunyai persepsi pada pengembangan teologi multikultural. ${ }^{5}$ Dengan diakuinya kebenaran teologi multikultural, berakhirlah teologi monokultural yang bersifat kolonialistik karena menekan dan menindas kultur-kultur lain. Represi terhadap komunitas adat dan religi seperti Kajang di

\footnotetext{
5 J.B. Banawiratma, "Kata Pengantar," in Meneliti Jemaat: Pedoman Riset Partisipatoris (Jakarta: Grasindo, 1997), x-xi.
} 
Bulukumba Sulawesi Selatan, Sunda Wiwitan di Jawa Barat, Marapu di Sumba, Seren Taun di Cigugur adalah deretan contoh aksi yang ditopang oleh praksis berteologi monokultur. ${ }^{6}$ Sebaliknya, kesadaran multikultural membentangkan fakta bahwa sekarang ini tidak lagi hanya ada satu pusat teologi, melainkan banyak pusat, pengembangan pendidikan teologi pun semakin pluri-centric dan makin interkultural dan interreligius. Kunci penting dalam konsep multikultural adalah sinergitas semua elemen masyarakat dan keterlibatan semua pihak dalam membangun kultur kemanusiaan demi damai sejahtera semua pihak. $^{7}$ Masyarakat multikultural berbasis pada penghormatan akan perbedaan dan penghargaan pada hak-hak asasi manusia yang sejatinya adalah anugerah (given).

Pendidikan multikultural berasal dari dua kata. Pendidikan berarti proses mengubah sikap dan tata laku seseorang atau sekelompok orang dalam usaha men-

\footnotetext{
${ }^{6}$ John C. Simon, Teologi Publik: Narasi Ideologi, Kekuasaan, Dan Agama (Yogyakarta: Kanisius, 2017), 48-49.

7 Katalina Tahaafe-Williams, "Churches in Ecumenical Transition: Toward Multicultural Ministry and Mission," International Review of Mission 101, no. 1 (April 1, 2012): 170, accessed October 15, 2020, https://www.questia.com/read/ 1G1-289360076/churches-in-ecumenical-transitiontoward-multicultural. Charise Pimentel, The (Im) Possible Multicultural Teacher: A Critical Approach to Understanding White Teachers'
}

dewasakan manusia melalui upaya pengajaran dan pelatihan; atau proses, cara, maupun perbuatan mendidik. Sedangkan, multikultural (isme) merupakan gejala pada seseorang atau suatu masyarakat yang ditandai oleh kebiasaan menggunakan lebih dari satu kebudayaan. ${ }^{8}$ Menurut Salili dan Hoosain, pendidikan multikultural berbasis pada beberapa asumsi filosofis. ${ }^{9}$ Pertama, asumsi utama adalah bahwa perbedaan budaya adalah sesuatu yang positif dan memperkaya pengalaman serta dapat menolong orang untuk saling belajar masingmasing budaya dan menjadi lebih baik serta lebih mengisi kemanusiaan. Program pendidikan multikultural bertanggung jawab merefleksikan keragaman latar belakang para murid di dalam sebuah kurikulum yang bersifat terbuka. Kedua, pendidikan multikultural diperuntukkan bagi semua orang (murid) dan tidak hanya bagi kelompokkelompok minoritas. Bagi kelompok mayoritas, mereka mendapat manfaat dari belajar dan memahami perbedaan-perbedaan bu-

Multicultural Work (Roterdam: Sense Publishers, 2017), 42, 95-96.

8 Panmilo Yangin, Gereja Dan Pendidikan Multikultural: Pilar Pembangunan Masa Depan Indonesia (Yogyakarta: Kanisius, 2010), 13. Suripto, "Teologi Pendidikan Multikultural," EDUKASI: Jurnal Pendidikan Islam 5, no. 1 (October 13, 2017): 111-130, accessed October 15, 2020, https://staim-tulungagung.ac.id/ejournal/ index.php/edukasi/article/view/272.

9 Richard Race, Multiculturalism and Education: Contemporary Issues in Education Studies (New York: Continuum, 2011), 11-12. 
daya. Bagi minoritas, mereka belajar untuk hidup hormat dan penuh respek atas masyarakat besar yang menjadi warna dominan sebuah sistem sosial. Pendidikan multikultural harusnya dapat diterapkan di semua sekolah, tidak hanya di sekolahsekolah dengan populasi minoritas yang banyak. Ketiga, perwujudan dari pengajaran ini adalah perjumpaan lintas budaya (a cross-cultural encounter). Para guru dan para murid memiliki latar belakang budaya masing-masing, demikian nilai-nilai, benda-benda, persepsi dan prasangka. Proses belajar dan mengajar dalam situasi kebudayaan berbeda-beda kiranya menjadi sebuah kebiasaan yang dihidupi secara sadar dan ditata dengan terencana.

Dalam perspektif teologi, maka pendidikan multikultural berarti proses pengembangan seluruh potensi manusia yang menghargai pluralitas dan heterogenitas. ${ }^{10}$ Pendidikan multikultural juga berarti proses pengembangan sikap dan tata laku seseorang atau sekelompok orang dalam usaha mendewasakan manusia melalui upaya

\footnotetext{
${ }^{10}$ Tabita Kartika Christiani, "Christian Education for Peace Building in the Pluralistic Indonesian Context," in Religion, Civil Society and Conflict in Indonesia, ed. Carl Sterkens, Muhammad Machasin, and Frans Wijsen (Zürich \& Berlin: LIT Verlag, 2009), 173-193.

11 Yangin, Gereja Dan Pendidikan Multikultural: Pilar Pembangunan Masa Depan Indonesia, 14. Agus Munadlir, "Strategi Sekolah Dalam Pendidikan Multikultural," Jurnal JPSD 2, no. 2 (November 23, 2016): 114-130, accessed October
}

pengajaran, pelatihan, proses, perbuatan dan cara-cara mendidik yang menghargai pluralitas dan heterogenitas secara humanistik. ${ }^{11}$ Pendidikan multikultur juga disebut sebagai sebuah paradigma baru, yaitu pendidikan yang mengarahkan peserta didik untuk bersikap dan berpandangan inklusif terhadap realitas masyarakat yang beragam. Ini juga pendidikan yang memberikan pemahaman kepada siswa dan masyarakat tentang realitas keanekaragaman dalam banyak aspek kehidupan. Pendidikan multikultural juga dapat disebut sebagai cara belajar untuk hidup dalam perbedaan menuju saling memahami (education for mutual understanding). ${ }^{12}$ Pendidikan teologi multikultural didefinisikan sebagai proses penyadaran dan perubahan perilaku melalui rangkaian kegiatan belajar dan mengajar menuju penerimaan pada perbedaan yang merupakan tatanan Ilahi.

Artikel ini mencoba menawarkan sumbangan Pete Ward untuk pendidikan teologi multikultural. Pendidikan teologi

15, 2020, http://journal.uad.ac.id/index.php/JPSD/ article/view/6030.

12 Yangin, Gereja Dan Pendidikan Multikultural: Pilar Pembangunan Masa Depan Indonesia, 15-16. Nana Najmina, "Pendidikan Multikultural Dalam Membentuk Karakter Bangsa Indonesia," JUPIIS: JURNAL PENDIDIKAN ILMU-ILMU SOSIAL 10 , no. 1 (June 29, 2018): 52, accessed October 15, 2020, http://jurnal.unimed.ac.id/2012/index.php/ jupiis. 
multikultural berarti proses belajar mengajar yang mengarahkan peserta didik untuk bersikap dan berpandangan inklusif terhadap realitas masyarakat yang beragam sebagai anugerah Allah bagi pengembangan masyarakat melalui sikap hormat dan respek pada perbedaan menuju penerimaan dan saling memahami. Tesis tulisan ini bahwa konteks multikultural menghadirkan wajah pendidikan teologi gereja yang kontekstual dan menjawab tantangan hari ini, yaitu wajah pendidikan yang ramah dan arahnya merangkul keragaman, rendah hati pada perbedaan sebagai anugerah dan terus belajar pada dunia di mana gereja hadir.

\section{METODE PENELITIAN}

Penelitian ini termasuk pembahasan kepustakaan (library research). ${ }^{13}$ Dalam penelitian ini akan dikaji bahan pustaka primer, yaitu tulisan Pete Ward tentang pendidikan, dan pustaka sekunder, yaitu tulisan yang membahas dan menjelaskan lebih lanjut topik pendidikan teologi multikultural. Metode yang digunakan dalam studi ini adalah metode kombinasi antara metode empiris dan teologis yang bersifat deskriptif-interpretatif-analitis. ${ }^{14}$ Disebut

13 Anton Bakker and Achmad Charris Zubair, Metodologi Penelitian Filsafat (Yogyakarta: Kanisius, 1990), 63.

${ }^{14}$ Ward, Liquid Ecclesiology: The Gospel and the Church, 201. Lihat juga J.W. Cresswell, Research Design: Qualitative, Quantitative, and Mixed Methods (London: SAGE Publications, 2003), 3. metode empiris karena berbasiskan pada pengalaman menggereja yang konkret dan salah satu pengalaman itu adalah gereja di konteks masyarakat multikultural. Sifat metode ini tidak sekadar uraian deskriptif mengenai pokok masalah dengan perihal yang menyekitari soal pendidikan teologi multikultural, tetapi yang tak kalah penting dan menentukan adalah interpretasi dan analisa mengapa dan atau bagaimana pokok masalah itu memberi dasar atas pilihan cara pandang, wacana yang dikembangkan bersama tradisi, teks, simbol, dengan sebabakibat yang mengonstruksi sebuah pendidikan teologi multikultural. Pada akhir pembahasan, kontribusi Peter Ward tentang teologi multicultural tersebut akan didialogkan dengan pengalaman konkret kehidupan menggereja GPIB.

Secara metodik, kunci penting dalam konsep pendidikan teologi multikultural adalah sinergitas semua elemen masyarakat yang berbasis pada pengalaman empiris berupa keterlibatan semua pihak dalam membangun kultur kemanusiaan demi konstruksi sebuah teologi damai sejahtera semua pihak. ${ }^{15}$ Dalam pendidikan

Lihat juga Yunita T. Winarno, "Suatu Refleksi Metodologi Penelitian Sosial," Jurnal Ilmiah Humatek 1, no. 3 (2008): 161

15 Tahaafe-Williams, "Churches in Ecumenical Transition: Toward Multicultural Ministry and Mission.” Yangin, Gereja Dan Pendidikan 
teologi multikultural, semakin sebuah individu atau komunitas terjalin dalam jaringan dengan komunitas lainnya, maka semakin individu atau komunitas itu memiliki modal sosial (social capital) yang membuatnya memiliki kemampuan untuk ikut mengonstruksi realitas ke arah menjadi lebih baik. Metode tersebut akan dipakai menjelaskan pertanyaan, apa sumbangan Pete Ward dalam mengonstruksi pendidikan multikultural.

\section{HASIL DAN PEMBAHASAN}

\section{Pendidikan Teologi Multikultural}

Pete Ward menyusun panduan pendidikan teologi untuk pembaruan gereja dengan memakai pendekatan Liquid Ecclesiology sebagai kombinasi antara metode empiris dan teologis. ${ }^{16}$ Disebut metode empiris karena berbasiskan pada pengalaman menggereja yang konkret. Salah satu pengalaman itu adalah gereja di konteks masyarakat multikultural, yaitu masyarakat yang beragam dalam nilai-nilai keyakinan dan sosial, artefak-artefak budaya, persepsi dan prasangka hingga perilaku-perilaku yang menerjemahkan hal-hal yang bersifat batiniah tersebut.
Di dalam panduan pendidikan teologi yang disusun oleh Ward itu terdapat lima elemen dasar bagi sebuah proses penyadaran dan perubahan karakter ke arah penerimaan dan saling memahami konteks multikultural. Seperti diakui Ward, kelima elemen dasar itu bekerja bukan sebagai sebuah versi dari lingkaran pastoral (pastoral cycle), tetapi kelima elemen tersebut bekerja simultan dalam proses melihat atau mengamati dan belajar dari data empiris berupa pengalaman multikultur. ${ }^{17}$ Kelima elemen eklesiologis ini kemudian ditempatkan kembali dalam konteks multikultural. Secara berurut akan dipaparkan kelima elemen tersebut.

Pertama, kontemplasi (contemplation). Maksudnya adalah melihat atau mengamati dan belajar menemukan Yesus Kristus sebagai sumber kebenaran dan hidup. Melihat berarti melihat Yesus Kristus dan belajar atas sebuah undangan ke dalam relasi dengan Allah Tritunggal. Pendidikan teologi dimulai dengan menolong gereja untuk bergerak dari bawah (bottom line), yaitu dari kenyataan masyarakat yang multikultur. Kunci dari melihat dan belajar adalah cinta (love), yaitu: cinta kepada Allah, cinta kepada gereja dan cinta kepada

\footnotetext{
${ }^{16}$ Ward, Liquid Ecclesiology: The Gospel and the Church, 201.

17 Ibid.
}

Multikultural: Pilar Pembangunan Masa Depan Indonesia, 10. 
dunia. ${ }^{18}$ Cinta yang demikian adalah cinta yang sama yang dibagikan dalam ibadah. Ibadah sendiri mengintegrasikan hal melihat dan belajar, di mana semua dipanggil ke dalam relasi dengan Yesus Kristus. Di dalamnya ada suasana kekeluargaan sebagai sesama umat Allah di setiap harinya. Ibadah menjadi aktivitas harian yang mensukacitakan karena membawa orang percaya masuk ke dalam hidup sehari-hari. Pendidikan teologi jadinya merupakan sebuah perjalanan di dalam Allah dan menuju Allah, serta mengarah pada keterlibatan konkret di dalam hidup sehari-hari demi sinergitas semua elemen keragaman masyarakat. ${ }^{19}$ Bagi gereja, gerakan ganda menuju Allah sekaligus menuju dunia ini menjadikan gereja hidup dan muda kembali atau dibarui kembali melalui karya Roh Kudus yang jejaknya ditemukan dalam dunia ini.

Menjadi hidup dan muda berarti berbuah di dalam kesatuan dengan Kristus (union with Christ). Di sini persoalan ibadah bukan diartikan sempit di seputar ritus dan liturgi, tetapi lebih dari itu adalah menghubungkan iman kepada Allah dengan pengalaman hidup sehari-hari. Di mana pendidikan Kristiani berfokus pada spiritualitas (growth in the vocation of the Spirit) melalui pengembangan cara berpikir tentang diri dan tentang dunia melalui perjuangan kasih, kebenaran, keadilan dan perdamaian, sebagai usaha menemukan orientasi yang benar terhadap ibadah kepada Yesus Kristus. Orang Kristen harus mulai menghubungkan aspek-aspek hidup mereka sendiri dalam tindakan gereja yang terbuka (a welcoming congregation), yakni terbuka pada konteks hari ini yang multikultural. Pertimbangan kritisnya bahwa ibadah adalah bagian dari cinta, yaitu cinta kepada Allah, cinta kepada gereja dan cinta kepada dunia yang beragam ini. Ketiganya tidak dapat dipisahkan dan membentuk paradigma cinta yang holistik kepada dunia milik Allah yang multikultur ini.

Aspek penting pendidikan teologi Kristiani adalah kontemplasi yang arahnya kepada Kristus. Keterarahan ini terhubung dengan penyembahan kepada Kristus yang dinyatakan oleh Injil. Bahwa Injil dibaca sebagai teks yang membuat pembacanya mengalami transformasi lewat kehadiran Allah yang ditemukan dalam sikap cinta kepada dunia. ${ }^{20}$ Pendidikan teologi dalam konteks multikultural hendaknya menemukan interaksi kreatif dengan kitab suci, bukan hanya sebagai studi biblis akademis, tetapi mengantar pada ibadah aktual melalui

\footnotetext{
${ }^{20}$ Ibid, 203.

${ }^{18}$ Ibid, 202.

${ }^{19}$ Ibid.
} 
pengalaman hidup sehari-hari di tengah komunitas multikultur seperti Indonesia, di mana umat Kristiani berdialog dan bekerjasama dengan orang-orang yang beragama lain. Ibadah tersebut terarah pada tujuan utama, yaitu ketaatan kepada Kristus yang hadir dalam konteks multikultural tersebut melalui berbagi praksis iman tentang suatu tema yang ditinjau dari berbagai agama, yang semua bisa menyumbang refleksi dan aksi tentang keadilan, perdamaian dan keutuhan ciptaan.

Kedua, refleksi/perenungan (reflexivity). Ibadah kepada Yesus Kristus menurut kitab suci menjadi sebuah perjalanan masuk ke dalam dunia, yaitu dunia yang multikultur. Dalam istilah pendidikan teologi, ini berarti bahwa hal-hal praktis yang ditemukan dalam pengalaman keseharian bersama orang lain dapat menolong orang beriman belajar menyadari di setiap harinya kehadiran Kristus seperti yang diwartakan dalam kitab suci. ${ }^{21}$ Di waktu bersamaan, usaha mempelajari kitab suci memberi dorongan bahwa pengalaman gereja hari ini di tengah konteks multikultur haruslah dihubungkan dengan kitab suci. Terjadilah apa yang disebut dialog antara teks kitab suci dan konteks multikultur. Ini adalah sebuah percobaan untuk me- nemukan konsep pendidikan teologi setelah menghubungkan Alkitab dengan konteks. Pola-pola refleksi teologis ini dibangun dalam kerangka teologi praktis dengan berfokus pada masalah-masalah yang ada di dalam konteks. Hal ini sangat berguna bagi terbentuknya sebuah spiritualitas tindakan yang menghadirkan hidup sehari-hari dan pengalaman hidup beriman ke dalam keberadaan Allah melalui proses kontemplasi hidup Yesus di dalam cerita-cerita Injil. $^{22}$ Begitu pula lewat proses belajar melalui doa dan ibadah terbangun reorientasi menuju kepada hidup Yesus di dalam kitab suci. Begitulah pendidikan teologi multikultural bermuara pada kesalehan sehari-hari melalui keterbukaan pada perjumpaan dengan orang lain yang hidup di konteks multikultural. Di situlah terbangun komitmen pada Injil, sekaligus ada keterbukaan pada konteks yang dihidupi, yaitu hormat dan respek pada multikulturalisme melalui sikap penerimaan dan saling memahami.

Ketiga, perhatian (attention). Pendidikan teologi hendaknya menyatu dalam praktik spiritual yang berproses dalam ibadah, doa dan membaca Alkitab. Pola kebiasaan fundamental ini berbasis pada proses belajar yang terus menerus. Model

${ }^{21}$ Ibid.

${ }^{22}$ Ibid, 204. 
belajar ini adalah semacam perhatian (attention) yang kata kuncinya relasi dan partisipasi. $^{23}$ Setiap partisipasi dalam proses belajar adalah sebuah proses yang berada dalam relasi dengan hidup Allah Trinitas. Di sini terdapat dua orientasi, yaitu pertama, kerendahan hati yang penting dipunyai oleh gereja, yang didukung oleh kesadaran diri sebagai sikap kritis pada hidup sehari-hari. Di sini tindakan setiap hari gereja adalah kritik-diri (self-critical). Gereja-gereja dan organisasi-organisasi Kristen melanjutkan usaha melihat kembali dirinya untuk membarui karya pelayanannya di tengah masyarakat yang beragam. Pendidikan teologi harus berorientasi pada transformasi diri melalui kerja-kerja sebagai orientasi dasar dari kerja akademik dan diskusi-diskusi yang menolong mengayakan partisipan. Orientasi kedua adalah sikap empati. ${ }^{24}$ Sikap empati di sini hendaknya menjadi atmosfir bagi usaha belajar melalui tindakan. Sikap empati ini kiranya menjadi ekspresi gereja yang memberi kepada orang-orang percaya kemampuan bagi perjalanan kekristenan mengenal dunia yang multikultural ini. Sikap empati di sini adalah pemosisian diri gereja dan orang Kristen selalu sebagai murid-murid (students) yang belajar pada kearifan dunia.

23 Ibid.

${ }^{24}$ Ibid, 205.
Tujuannya adalah melihat pekerjaan Allah dan belajar pada karya yang dilakukan oleh Roh Kudus di tengah-tengah dunia ini. Akhirnya, tujuan pendidikan teologi yang berbasis penelitian empiris hendaknya menjadi arah bagi semua usaha memperbaiki pelayanan dan kepemimpinan di tengah dunia yang beragama ini. ${ }^{25}$ Di mana konteks multikultural ditanggapi bukan dengan sikap keras dan menolak, sebaliknya dengan sikap rendah hati dan empati seorang murid yang ingin belajar melayani dan menerapkan praksis kepemimpinan di tengah dunia ini.

Keempat, konstruksi (construction). Tujuan dan produk pendidikan teologi membutuhkan kesadaran. Produknya bertujuan untuk menulis secara lebih baik narasi tentang pembaruan gereja. Pembaruan gereja adalah ekspresi iman sekaligus imperatif yang berasal dari kesadaran akan perubahan konstruksi dunia budaya yang multi-dimensi, multikultural. ${ }^{26}$ Menulis narasi pembaruan gereja adalah proses yang di dalamnya ada kontemplasi, refleksi, perhatian dan konstruksi mendalam akan kesadaran sekaligus tindakan nyata. Tetapi proses ini tidak berakhir pada produk saja. Karena menulis kisah gereja yang dibarui adalah sebuah proses pendidikan teologi

\footnotetext{
25 Ibid, 207.

${ }^{26}$ Ibid.
} 
yang menolong bagi sebuah generasi untuk membarui gereja agar kehadirannya relevan di konteks yang berubah. Dalam proses pendidikan itu, setiap siswa mengonstruksi model-model menggereja (komunitas) yang relevan dan model-model misi (komunikasi) yang kontekstual. Khususnya dalam konteks multikultural, maka pendidikan teologi multikultur membutuhkan kesadaran gereja, bahwa di dalam budaya apapun termasuk dalam budaya populer yang serba digital sesungguhnya Allah hadir, sehingga terbentuk model komunitas dan komunikasi yang baru yang lebih terbuka pada berbagi praksis iman. Di mana masyarakat multikultural menandai kehadiran Allah yang juga lahir dan hadir di dalam budaya-budaya manusia.

Kelima, menyusun proposal dan memeriksa tindakan (expanding the fragments and editing expression). Dalam Liquid Ecclesiology diargumenkan bahwa ekspresi budaya yang cair (baca: multikultur) berkelindan dengan kehadiran Kristus melalui kuasa Roh Kudus di tengah dunia yang beragama ini. Perspektif ini berasumsi bahwa di mana saja ada masalah atas hidup, maka hal itu disebabkan karena ekspresi budaya adalah kompleks, banyak sudut pandang dan saling kontradiktif (complex, multi-layered and contradictory). ${ }^{27}$ Pendidikan teologi bukanlah sesuatu yang terpisah, melainkan bagian dari hidup gereja yang menyatu dengan ibadah dan doa serta spiritualitas tindakan menuju program pendidikan yang konkret. Proposal ini merupakan pengalaman yang diekspresikan lewat keberadaan dan hidup gereja di tengah dunia yang multikultural ini sebagai dasar bagi pembelajaran dan pembaruan praksis. Proposal ini adalah bahwa pendidikan teologi harus dimulai melalui cara-cara bersikap orang percaya menemukan Allah dalam berteologi di keseharian yang multikultural. Ward hendak melampaui paradigma teologi tradisional yang skolastik (tertutup di dalam istana dan biara) dan bersifat monokultur, menjadi teologi dari bawah (theology from below), yakni dari pengalaman konkret berjumpa dengan yang lain dengan seluruh keragamannya serta bersifat multikultur.

Pendekatan bagi pendidikan teologi ini meneguhkan upaya menemukan Allah dalam kekuatan Roh dan khususnya dalam ibadah di konteks keseharian. Maksud dari semua ini adalah terbentuknya titik masuk yang kreatif dalam membangun pendidikan teologi multikultural dengan membentangkan berbagai variasi tema biblika dan

${ }^{27}$ Ibid, 208.

141 CopyrightC 2020, Dunamis, ISSN 2541-3937 (print), 2541-3945 (online) 
teologi sebagai wacana gereja yang terus menjadi. ${ }^{28}$ Pendidikan teologi harusnya menolong siswa-siswa membangun referensi-referensi dan memberi mereka sebuah konteks yang besar bagi pendalaman atas kekayaan narasi biblis dan teologis, yaitu konteks multikultural. Dan yang terpenting bahwa pendidikan teologi tersebut membuat nara didik mengalami pengalaman bersinergi melalui keterlibatan dan partisipasi dalam ekspresi dan tindakan seharihari gereja yang hidup di tengah-tengah masyarakat multikultural yang dicirikan oleh sifatnya yang kompleks, banyak sudut pandang dan saling kontradiktif (complex, multi-layered and contradictory). Di pustaka lain, Liquid Church, Pete Ward mengidentifikasi konteks hari ini yang "terus bergerak", "berubah-ubah", "cair" dan "fleksibel" (mobile, mutable, fluid, flexible). ${ }^{29}$ Dalam kesadaran konteks yang telah berubah itulah, pendidikan teologi multikultural bermaksud membuat praksis gereja relevan dan kontekstual. Relevan ke dalam bagi umatnya sendiri karena dapat mengembangkan sikap rendah hati dan empati, dan kontekstual dengan keluar

\footnotetext{
${ }^{28}$ Ibid, 209.

29 Pete Ward, Liquid Church (Eugene \& Oregon: WIPF \& STOCK, 2002), 14-15.

30 Yayah Khisbiyah, "Membangun Harmoni Di Masyarakat Plural: Pandangan Psikologi Dan Pedagogi Perdamaian," in Politik Identitas Dan Masa Depan Pluralisme Kita, ed. Ihsan Ali-Fauzi and Samsu Rizal Panggabean (Jakarta: PUSAD
}

menata hidup penuh hormat dan respek di tengah masyarakat.

Kelima panduan pendidikan teologi di atas adalah sebuah proses yang bergerak simultan melalui gerak melihat dan belajar lewat keterlibatan nyata. Dalam pendidikan teologi multikultural itu, maka konteks multikultural sebagai fakta empiris menjadi imperatif bagi gereja menampilkan wajah barunya, bukan hanya sebagai "gereja yang mengajar" (ecclesia docens) dunia tentang keadilan, perdamaian dan keutuhan ciptaan, melainkan "gereja yang belajar" (ecclesia discens) dari dunia dalam rangka menemukan jejak-jejak Allah di dalam seluruh potensi dan kebudayaan manusia. Dalam konteks pendidikan teologi multikultural ini, salah satu tugas utama agama yang strategis dan mendesak dilakukan adalah membentuk karakter pasifis atau cinta damai di kalangan partisipan pendidikan, serta menginternalisasikan sikap toleran dan apresiatif terhadap perbedaan dan kebhinneka-an. ${ }^{30}$ Dalam bahasa Ward, konteks multikultural menghadirkan wajah gereja yang baru, yaitu wajah yang terbuka dan ramah karena maksudnya merangkul

Yayasan Wakaf Paramadina, NPN dan MPRKUGM, 2010), 81-93 (87). Jozef M.N. Hehanussa, "Working Together for Peace," in Mendesain Ulang Pendidikan Teologi: Buku Penghormatan Untuk Pdt. Em. Judowibowo Poerwowidagdo, MA, Ph.D (Yogyakarta: Duta Wacana University Press, 2012), 106-115. 
perbedaan, rendah hati pada pandangan dan keyakinan lain dan terus belajar pada dunia di mana gereja hadir untuk menemukan jejak-jejak Allah. Itulah wajah gereja multi- kultural, yaitu wajah dari pendidikan Kristiani yang siap berbagi praksis iman yang menghidupkan ruang hidup bersama.

(1)

Kontemplasi

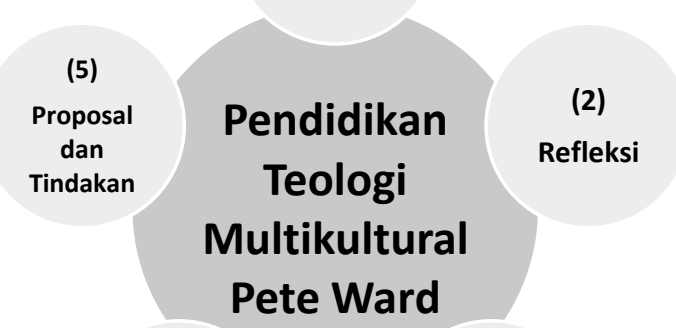

(4)

(3)

Konstruksi

Perhatian

Bagan 1: Lima Elemen Dasar Pendidikan Teologi Multikultural Pete Ward

Pemikiran Pete Ward tentang konteks budaya populer yang bersifat kompleks, banyak sudut pandang dan saling kontradiktif (complex, multi-layered and contradictory) atau "terus bergerak," "berubah-ubah." "cair" dan "fleksibel" (mobile, mutable, fluid, flexible) dikembangkan secara progresif oleh seorang teolog dari Universitas Pretoria yang bernama Wim A. Dreyer. $^{31}$ Ia mengatakan bahwa menjadi gereja di abad 21 ini sungguh berbeda dengan menjadi gereja di abad 1. Abad 21 ini membawa manusia di planet ini tiba

\footnotetext{
31 Wim A. Dreyer, "Being Church in the Era of 'Homo Digitalis," Verbum et Ecclesia 40, no. 1
}

pada era budaya digital dan manusia pun menjadi manusia digitalis. Salah satu penandanya adalah jaringan komunikasi berbasis digital yang memasuki relasi-relasi individual. Jalur-jalur komunikasi yang menghubungkan setiap individu dan kelompok-kelompoknya menghasilkan apa yang disebut sebagai "masyarakat cair" (liquid society), yaitu masyarakat yang serba terhubung melalui jaringan nirkabel.

Revolusi industri 4.0 yang berbasiskan digitalisasi dan otomasi tidak hanya mengubah apa yang kita lakukan

(2019): 1-7, accessed October 15, 2020, https://doi.org/10.4102/ve.v40i1.1999. 
(what we do), tetapi juga siapa kita (who we are). ${ }^{32}$ Perubahan signifikan dalam diri manusia (who we are), yaitu menjadi manusia digitalis, telah mengubah pandangannya terkait keberagamaan. Dalam perspektif pendidikan Kristen, homo digitalis mentransformasi gereja untuk semakin dinamis membentuk gambarannya tentang gereja di dunia siber (being church in the cyberworld). ${ }^{33}$ Dampak yang langsung terlihat adalah pada pendidikan warga gereja berupa pola peribadatan atau liturgi, yang semakin cair, dinamis dan bergerak terus, karena berbasis "dalam jaringan" (daring, online). Gereja kemudian bertransformasi menjadi komunitas virtual, yang melakukan berbagai kegiatannya, mulai dari ibadah, pendidikan dan pembinaan, konseling, pastoral hingga penataan organisasi, pun dilakukan secara virtual. Tak terkecuali dalam pelaksanaan sakramen-sakramen dapat dilaksanakan secara daring (online). Inilah praksis pedagogi gereja dalam dunia siber, yaitu pendidikan di dunia serba digital.

Praksis pendidikan di dunia serba digital bertujuan mengantar manusia sebagai homo digitalis menjadi pengguna

\footnotetext{
32 Ward, Liquid Church, 14-15. Dreyer, "Being Church in the Era of 'Homo Digitalis."' Zygmunt Bauman, Liquid Modernity (Malden: Polity Press, 2006), 6.
}

teknologi yang bertanggung jawab, ramah dan tidak anti sosial, terbuka pada kehadiran yang lain dalam sikap respek dan hormat, dan kritis pada dampak negatif perkembangan teknologi di era industri 4.0 ini. Dalam rangka mencapai tujuan pendidikan teologi multikultural, maka manusia sebagai pelaksana sekaligus sasaran dari pendidikan itu diarahkan mengalami transformasi diri dalam kognisi (pengetahuan), afeksi (sikap dan nilai) dan psikomotori (keterampilan) yang holistik. Dengan memanfaatkan teknologi dari era industri 4.0 ini, manusia sebagai makhluk digital mampu mengembangkan kompetensi membangun sinergitas dengan semua elemen masyarakat yang berbasis pada pengalaman empiris berupa keterlibatan dalam membangun kultur kemanusiaan demi konstruksi sebuah pendidikan teologi multikultural tentang damai sejahtera semua pihak.

\section{GPIB sebagai Gereja Multikultural}

Dari pembahasan teoritis di atas, saya sekarang ingin menyinggung ke konteks yang lebih sempit, yakni gereja di mana saya menjadi anggota, untuk memberi bentuk pada proposal dan tindakan (ex-

\footnotetext{
33 Dreyer, "Being Church in the Era of "Homo Digitalis."”
} 
panding the fragments and expression) Pete Ward bagi pendidikan teologi multikultural. Menurut saya, dinamika eklesiologi GPIB dapat menjadi titik hubung dalam menjelaskan apa yang Ward maksud dengan pendidikan teologi multikultural. Hal ini ditopang juga oleh dokumen GPIB yang jelas-jelas menyebut bahwa GPIB adalah gereja multikultural.

Dari tradisi sistematis Gereja Protestan di Indonesia bagian Barat (GPIB), seperti yang tertulis dalam buku sejarah GPIB, Bahtera Guna Dharma yang terbit pertama kali 1981, dikatakan di sana, "Eksistensi GPIB adalah multikultural karena di dalamnya terhimpun berbagai suku, latar belakang, bahasa dan kebudayaan."34 Kutipan di atas menjelaskan tentang satu model eklesiologi yang dipakai GPIB hari ini, yaitu model gereja multikultural. Konsep eklesiologi seperti ini sayangnya bagi GPIB seperti "penemuan kembali" (rediscovery). Lama sekali GPIB tidak pernah menyadari tradisinya sendiri ini apalagi mendiseminasikannya menjadi sebuah wacana dan praksis pendidikan teologi GPIB di lingkup internal termasuk di ruang publik

${ }^{34}$ S.W. Lontoh and H. Jonathans, Bahtera Guna Dharma GPIB (Jakarta: BPK Gunung Mulia, 2014), 67-68. S.W. Lontoh and H. Jonathans, eds., Bahtera Guna Dharma Gereja Protestan Di Indonesia Bagian Barat (Jakarta: MS GPIB XII dan LPPP, 1981), 80f. multikultur. Dengan penemuan kembali tradisinya sebagai gereja multikultural, GPIB seharusnya siap memasuki dialog publik dengan mengusung nilai-nilai multikultural berupa solidaritas, keadilan dan kesetaraan. Dan dalam rangka pendidikan multikultural, GPIB dapat menjadi komunitas contoh bagi pengembangan sikap hidup yang menghargai keragaman dengan pertama-tama mengakui keragaman di tubuh GPIB sendiri.

Mengapa model gereja multikultural penting didiseminasikan? Karena salah satu model eklesiologi yang selama ini GPIB wacanakan dan usung, yaitu gereja misioner, belum cukup memadai bila ditempatkan dalam konteks masyarakat yang multikultur. Dalam evaluasinya, ${ }^{35}$ saya pernah mengatakan bahwa paradigma gereja misioner tumbuh dari kenyataan minoritas Kristen (syndrom minority complex) di satu pihak, dan kemajemukan masyarakat yang multifaset di pihak lain, yang keduanya merupakan konteks dari jemaatjemaat di Indonesia dalam membangun praksis pendidikan teologi warga jemaat di dalam konteks. Paradigma gereja misioner

\footnotetext{
${ }^{35}$ Stella Y.E. Pattipeilohy, "Teologi Publik Menurut Preman Niles Dan Relevensinya Bagi Konstruksi Teologi Publik Kristiani Di GPIB" (Universitas Kristen Duta Wacana, 2018), 145-147. Lihat juga Stella Y.E. Pattipeilohy, Teologi Publik Asia Menurut Preman Niles: Sebuah Sketsa Membangun Teologi Publik GPIB (Yogyakarta: Kanisius, 2019), 162-163.
} 
sangat kuat dengan sindrom minoritas dan kehilangan Injil sosial, yang tanpa sadar tugas Kristiani secara sempit dibangun oleh misinya untuk membawa segala sesuatu masuk ke dalam gereja, bukan ke dalam hidup Allah. Di sini keselamatan dimengerti eksklusif sebagai bersumber dari dalam gereja, bukan bersumber pada hidup Allah. Semangat zaman di belakang rumusan gereja misioner jelas adalah pendekatan "gereja-sentris" (church-centred), misi penanaman gereja (plantatio ecclesia) dan penaklukkan. Dimensi Kristosentris dalam konsep gereja misioner juga dimaknai sempit karena semua ritus berakhir pada institusi (gereja) dengan menggambarkan Kristus secara tertutup bagi yang lain. Kristus ditempatkan sebagai lawan bagi yang lain (agama-agama dan kebudayaan-kebudayaan lain) dan kepenuhan yang lain (agama dan budaya lain) hanya bila masuk ke dalam kebudayaan Kristen Barat (westernisasi).

Saya sependapat dengan John Simon, ${ }^{36}$ yang menggambarkan bahwa model gereja multikultural sangat relevan dijadikan model bagi pengembangan GPIB yang kontekstual termasuk dalam praksis pendidikan teologinya. Di konteks GPIB,

\footnotetext{
${ }^{36}$ John C. Simon, "Sejarah GPIB Dan Eksperimen Menggereja Kontekstual: Tentang Eksperimen Eklesiologi Multikultural," in Gereja Orang
}

model gereja multikultural menunjuk fakta diri berupa struktur dalam dan struktur luar. Struktur dalam menunjuk bahwa di dalam GPIB terhimpun berbagai suku, latar belakang, bahasa dan kebudayaan. Sementara struktur luar menunjuk pada perilaku sosial baik secara individual dan kolektif di ruang-ruang publik yang dimasuki GPIB. Baik struktur dalam dan luar keduanya membentuk kesatuan holistik sebuah gerak panggilan dan pengutusan GPIB di berbagai bidang termasuk bidang pendidikan teologi Kristiani yang multikultural. Isi dari praksis pendidikan teologi multikultural khas GPIB adalah panggilan menjadi gereja dan warga jemaat yang menghadirkan damai sejahtera dalam pergaulan luas yang lintas iman dan lintas budaya, dengan sikap hormat dan respek pada perbedaan, memperjuangkan hak-hak kelompok rentan dan prihatin pada usaha-usaha menuju keutuhan ciptaan.

Dalam catatan sejarah, model eklesiologi monokultural bisa disematkan pada GPIB di periode 1948-1960. GPIB monokultur yang dimaksud didasarkan pada masih kentalnya GPIB sebagai gereja warisan kolonial berwajah parokial, dan secara parokial pula tugasnya cuma memelihara jiwa-jiwa dalam pola kekristenan

Merdeka: Eklesiologi Pascakolonial Indonesia, ed. Zakaria J. Ngelow (Makassar: Yayasan OASE INTIM, 2019), 239-267. 
benteng serta berorientasi ke dunia yang akan datang. Pada periode monokultur ini, buku sejarah GPIB, Bahtera Guna Dharma, mencatat:

Sejak tahun 1948 hingga 1960, jemaat-jemaat terlampau parokial, yang melihat tugas utamanya: menjadikan anggota-anggotanya saleh di dunia ini dan dalam dunia yang akan datang. Satu ciri khas dari jemaat demikian ialah, bahwa pekerjaan pelayanan dilakukan oleh para pejabat gereja saja, terutama oleh para pendeta. Gereja pada waktu itu disebut: "Gereja Pendeta." Dengan pengesahan Tata Gereja baru di tahun 1962 masalahmasalah pokok belum juga terjawab. Sejak itu, ciri-ciri jemaat parokial masih tetap melekat pada gereja, hanya para penatua dan diaken sekarang memegang peranan yang besar. Gereja dengan itu menjadi suatu "Gereja Majelis Jemaat." ${ }^{, 37}$

Sifat monokultur juga jelas pada tugas utama gereja di bidang pendidikan teologi umat yang bersifat monokultur, yaitu memelihara kesalehan umat yang tertutup dari interaksinya dengan konteks sekitar. Misi monokultur di bidang pendidikan berarti misi ke dalam diri sendiri, yang ditunjang oleh pola kekristenan

\footnotetext{
${ }^{37}$ Ibid.

38 Stella Y.E. Pattipeilohy, "Ketuhanan Yang BerkebudayaanKetuhanan Yang Berkebudayaan: Memahami Pancasila Sebagai Model Interkulturalitas," GEMA TEOLOGIKA 3, no. 2 (October 26, 2018): 121-146, accessed October 15, 2020, http://journal-theo.ukdw.ac.id/index.php/ gemateologika/article/view/363. Handri Yonathan,
}

benteng dan pengaruh Reformasi jilid dua, yaitu pietisme, yang secara sempit dipahami sebagai kesalehan ke dalam, bukan sebaliknya mengusahakan transformasi sosial. Ciri lain dari monokultur adalah tugas pelayanan gerejawi berpusat pada pejabat gereja sehingga secara sempit gereja disebut sebagai "gereja pendeta" dan "gereja majelis jemaat." Karena itu ke depan, tugas GPIB adalah mendiseminasikan GPIB multikultural sebagai modal sosial bagi pendidikan teologi warga gereja dan menjadi strategi ruang publik eksternal (semacam teologi publik GPIB). Salah satu strategi ruang publik eksternal adalah mengajukan sebuah proposal pendidikan teologi multikultural tentang bagaimana warga GPIB menjadi warga gereja yang terbuka, hidup adil, penuh belarasa dan solidaritas yang lintas iman dan kebudayaan. ${ }^{38}$ Hanya dengan upaya inilah, maka sinergitas seluruh komponen keragaman dapat diwujudkan dalam keterlibatan nyata gereja dan warganya pada pembentukan masyarakat multikultur.

Akhirnya, saya sependapat dengan John Simon, ${ }^{39}$ yang memperjelas nilai-nilai

\footnotetext{
"Historisitas Gereja Protestan Indonesia Bagian Barat Penabur Surakarta Sebagai Potensi Objek Wisata Religi," EPIGRAPHE: Jurnal Teologi dan Pelayanan Kristiani 2, no. 1 (July 20, 2018): 14-31, accessed October 15, 2020, http:// www.stttorsina.ac.id/jurnal/index.php/epigraphe.

${ }^{39}$ John C. Simon, "Lima Nilai Teologi Publik GPIB Untuk Dialog Publik," in Teologi Publik Asia
} 
pendidikan teologi multikultural GPIB yang penting diusung dalam dialognya di tengah-tengah konteks yang dimasukinya. Nilai-nilai itu sekaligus menjadi nilai hidup menggereja menurut model Yesus Kristus, yang tidak lain merupakan nilai-nilai pendidikan teologi multikultural, yaitu pembaruan, perdamaian, pertobatan, pengosongan diri (kenosis) dan kesederhanaan (ke-ugahari-an). Nilai-nilai ini pun sejalan dengan kelima proposal Pete Ward. Pertama, pembaharuan adalah usaha membangun dan menyusun kembali jawabanjawaban kita terhadap panggilan Ilahi dari gereja di tengah-tengah keadaan masyarakat yang sedang berubah. Menurut saya, nilai ini sejalan dengan aspek kontemplasi (contemplation) menurut Ward, yaitu aspek keterlibatan dalam hidup Allah dan dalam dunia milik Allah. Kedua, perdamaian, yang bersangkut paut dengan respek dan kasih terhadap orang lain, serta mempunyai perhatian dan pengertian terhadap keadaan orang lain, yang menimbulkan kewajiban untuk meneliti dan mengetahui serta memahami keadaan orang lain itu, baik ia orang Kristen yang bekerja sama, baik ia bukan orang Kristen yang dilayani menurut kesaksian Injil. Menurut saya, nilai ini sejalan dengan aspek refleksi/perenungan (reflexivity) menurut Ward, yang berarti bahwa ibadah sebagai pengalaman intim dengan Allah menjadi sebuah perjalanan memasuki dunia dalam laku dialog dan kerjasama. Ketiga, pertobatan, yaitu suatu ketaatan baru terhadap iman yang "melihat" apa yang Allah sedang lakukan di duniaNya pada masa kini. Dan sebagai akibatnya, ketaatan baru itu membina secara baru pula suatu pandangan (visi) tentang maksud Allah dengan sejarah dunia dan gereja. Menurut saya, nilai ini sejalan dengan aspek perhatian (attention) menurut Ward, yang berisikan praktik spiritual dalam relasi dan partisipasi dengan Allah Tritunggal, serta mengusung dua orientasi, yaitu kerendahan hati dan empati sebagai seorang murid yang belajar pada dunia untuk menemukan jejak Allah di sana. Keempat, pengosongan diri (kenosis), yakni bahasa perlawanan terhadap cara berpikir egologis yang menempatkan aku sebagai pusat segala sesuatu. Bagi gereja, kenosis adalah panggilan menjadi gereja yang terbuka dan berdialog rangkap tiga dengan dunia ini, yaitu: agama lain, kebudayaan lain dan orang miskin. Menurut saya, nilai ini sejalan dengan aspek konstruksi (construc-

Menurut Preman Niles: Sebuah Sketsa Membangun Teologi Publik GPIB (Yogyakarta: Kanisius, 2019), xiii-Xx. 
tion) menurut Ward, bahwa tujuan dan produk pendidikan teologi multikultural adalah berbagi praksis iman, yang hanya dimungkinkan bila para pesertanya samasama mengalami kenosis ganda (pengosongan diri ganda) dengan memberi ruang pada kehadiran yang lain. Dan kelima, kesederhanaan (ke-ugahari-an), yang secara eksternal menggambarkan perilaku hidup lembut, tenang, sahaja, ugahari (artinya sedang, sederhana). Kesederha-naan muncul sebagai hasil pengekangan, pengendalian dan pengaturan. Kesahajaan merupakan perilaku seseorang yang tahu batas, tahu menahan diri, tahu mengekang nafsu, sehingga memiliki ketahanan hati dan tidak jatuh dalam perilaku ekstrem atau berlebih-lebihan. Menurut saya, nilai ini sejalan dengan aspek menyusun proposal dan memeriksa tindakan (expanding the fragments and editing expression) menurut Ward. Proposal ini adalah bahwa pendidikan teologi multikultural harus dimulai dalam cara-cara bersikap orang percaya menemukan Allah dalam berteologi di keseharian yang multikultural. Kesemua nilai hasil dialog antara nilai-nilai GPIB dan pemikiran Pete Ward ini sekaligus sebuah proposal tentang gagasan pendidikan teologi yang gereja kerjakan di konteks multikultural.

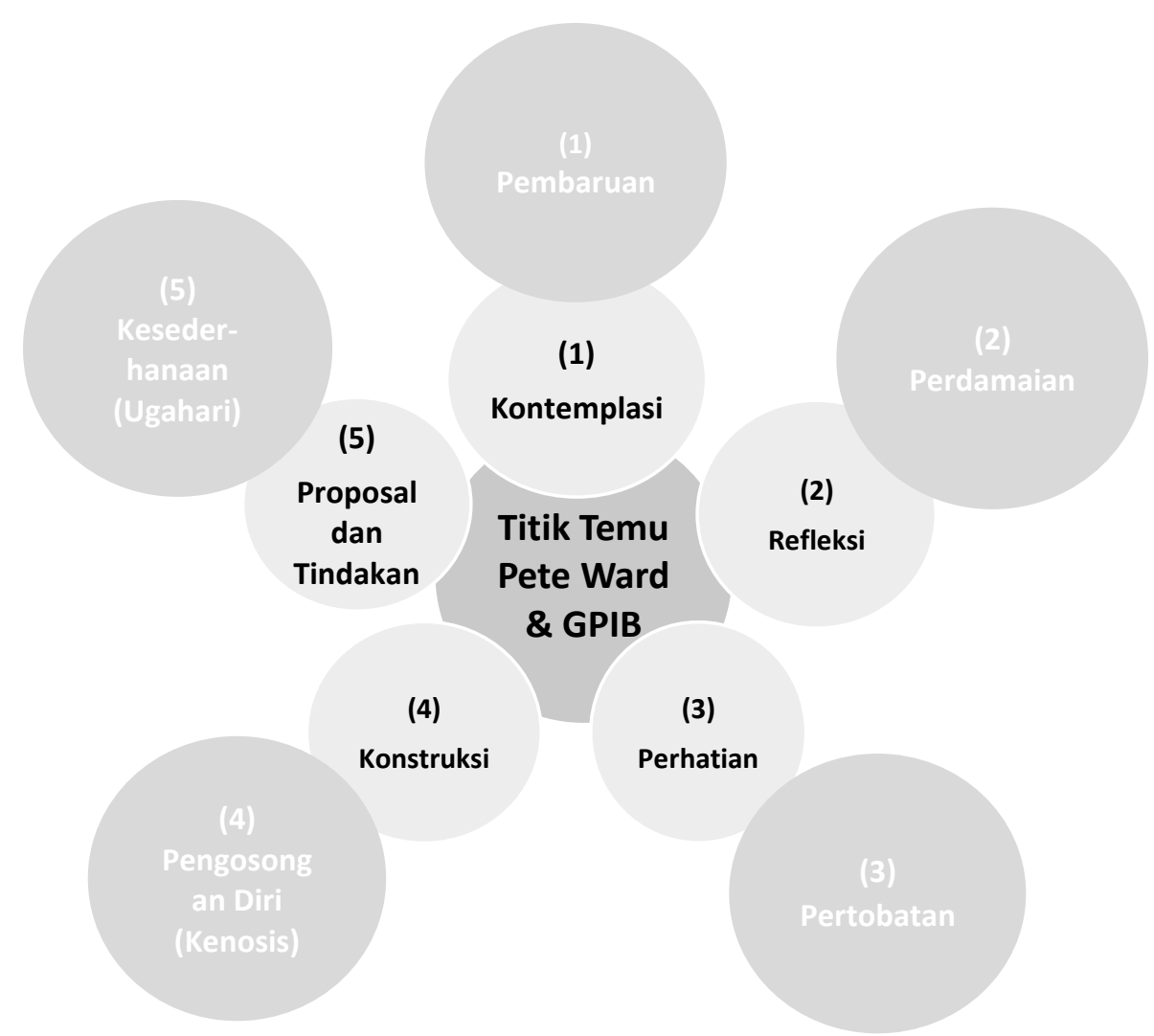

Bagan 2: Titik temu Aspek Pendidikan Pete Ward dan Nilai Pendidikan GPIB 


\section{KESIMPULAN}

Pendidikan teologi multicultural haruslah dikonstruksikan dalam konteks multikultural itu sendiri. Artinya bahwa masyarakat multikultural sebagai sebuah data empiris akan terhubung dengan pengalaman keseharian di mana komunitas gereja memberi respon dengan mengonstruksi model gereja multikultural. Masyarakat multikultural sendiri bercirikan kompleks, banyak sudut pandang dan saling kontradiktif (complex, multi-layered and contradictory) atau "terus bergerak," "berubah-ubah," "cair" dan "fleksibel" (mobile, mutable, fluid, flexible). Dalam konteks demikian, maka konstruksi gambaran eklesiologi (komunitas) dan misiologi (komunikasi) gereja adalah gereja yang terbuka, ramah dan merangkul perbedaan, yang rendah hati menerima yang lain sebagai teman seperjalanan dalam menemukan jejak-jejak Allah dalam kebudayaan manusia, dan yang belajar dari dunia milik Allah.

\section{DAFTAR PUSTAKA}

Bakker, Anton, and Achmad Charris Zubair. Metodologi Penelitian Filsafat. Yogyakarta: Kanisius, 1990.

Banawiratma, J.B. "Kata Pengantar." In Meneliti Jemaat: Pedoman Riset Partisipatoris. Jakarta: Grasindo, 1997.

Bauman, Zygmunt. Liquid Modernity.
Malden: Polity Press, 2006.

Christiani, Tabita Kartika. "Christian Education for Peace Building in the Pluralistic Indonesian Context." In Religion, Civil Society and Conflict in Indonesia, edited by Carl Sterkens, Muhammad Machasin, and Frans Wijsen. Zürich \& Berlin: LIT Verlag, 2009.

Cresswell, J.W. Research Design: Qualitative, Quantitative, and Mixed Methods. London: SAGE Publications, 2003.

Dreyer, Wim A. "Being Church in the Era of 'Homo Digitalis." Verbum et Ecclesia 40, no. 1 (2019): 1-7. Accessed October 15, 2020. https://doi.org/.

Hehanussa, Jozef M.N. "Working Together for Peace." In Mendesain Ulang Pendidikan Teologi: Buku Penghormatan Untuk Pdt. Em. Judowibowo Poerwowidagdo, MA, Ph.D. Yogyakarta: Duta Wacana University Press, 2012.

Khisbiyah, Yayah. "Membangun Harmoni Di Masyarakat Plural: Pandangan Psikologi Dan Pedagogi Perdamaian." In Politik Identitas Dan Masa Depan Pluralisme Kita, edited by Ihsan AliFauzi and Samsu Rizal Panggabean. Jakarta: PUSAD Yayasan Wakaf Paramadina, NPN dan MPRK-UGM, 2010.

Lontoh, S.W., and H. Jonathans, eds. Bahtera Guna Dharma Gereja Protestan Di Indonesia Bagian Barat. Jakarta: MS GPIB XII dan LPPP, 1981.

- Bahtera Guna Dharma GPIB. Jakarta: BPK Gunung Mulia, 2014.

Munadlir, Agus. "Strategi Sekolah Dalam Pendidikan Multikultural." Jurnal JPSD 2, no. 2 (November 23, 2016): 
114-130. Accessed October 15, 2020. http://

journal.uad.ac.id/index.php/JPSD/arti cle/view/6030.

Najmina, Nana. "Pendidikan Multikultural Dalam Membentuk Karakter Bangsa Indonesia." JUPIIS: JURNAL PENDIDIKAN ILMU-ILMU SOSIAL 10, no. 1 (June 29, 2018): 52. Accessed October 15 , 2020.

http://jurnal.unimed. ac.id/2012/index.php/jupiis.

Pattipeilohy, Stella Y.E. "Ketuhanan Yang BerkebudayaanKetuhanan Yang Berkebudayaan: Memahami Pancasila Sebagai Model Interkulturalitas." GEMA TEOLOGIKA 3, no. 2 (October 26, 2018): 121-146. Accessed October 15, $2020 . \quad$ http://journaltheo.ukdw.ac.id/index.php/ gemateologika/article/view/363.

- Teologi Publik Asia Menurut Preman Niles: Sebuah Sketsa Membangun Teologi Publik GPIB. Yogyakarta: Kanisius, 2019.

. "Teologi Publik Menurut Preman Niles Dan Relevensinya Bagi Konstruksi Teologi Publik Kristiani Di GPIB." Universitas Kristen Duta Wacana, 2018.

Pimentel, Charise. The (Im) Possible Multicultural Teacher: A Critical Approach to Understanding White Teachers' Multicultural Work. Roterdam: Sense Publishers, 2017.

Race, Richard. Multiculturalism and Education: Contemporary Issues in Education Studies. New York: Continuum, 2011.

Simon, John C. "Lima Nilai Teologi Publik GPIB Untuk Dialog Publik." In Teologi Publik Asia Menurut Preman Niles: Sebuah Sketsa Membangun Teologi Publik GPIB. Yogyakarta: Kanisius, 2019.
"Sejarah GPIB Dan Eksperimen Menggereja Kontekstual: Tentang Eksperimen Eklesiologi Multikultural." In Gereja Orang Merdeka: Eklesiologi Pascakolonial Indonesia, edited by Zakaria J. Ngelow. Makassar: Yayasan OASE INTIM, 2019.

- Teologi Publik: Narasi Ideologi, Kekuasaan, Dan Agama. Yogyakarta: Kanisius, 2017.

Suripto. "Teologi Pendidikan Multikultural." EDUKASI: Jurnal Pendidikan Islam 5, no. 1 (October 13, 2017): 111-130. Accessed October 15, $2020 . \quad$ https://staimtulungagung.ac.id/ejournal/index.php/ edukasi/article/view/272.

Tahaafe-Williams, Katalina. "Churches in Ecumenical Transition: Toward Multicultural Ministry and Mission." International Review of Mission 101, no. 1 (April 1, 2012): 170. Accessed October 15 , 2020. https://www.questia.com/read/1G1289360076/churches-in-ecumenicaltransition-toward-multicultural.

Ward, Pete. Liquid Church. Eugene \& Oregon: WIPF \& STOCK, 2002.

_. Liquid Ecclesiology: The Gospel and the Church. Leiden \& Boston: Brill, 2017.

Winarno, Yunita T. "Suatu Refleksi Metodologi Penelitian Sosial.” Jurnal Ilmiah Humatek 1, no. 3 (2008): 161.

Yangin, Panmilo. Gereja Dan Pendidikan Multikultural: Pilar Pembangunan Masa Depan Indonesia. Yogyakarta: Kanisius. 2010

Yonathan, Handri. "Historisitas Gereja Protestan Indonesia Bagian Barat Penabur Surakarta Sebagai Potensi Objek Wisata Religi." EPIGRAPHE: Jurnal Teologi dan Pelayanan 
Kristiani 2, no. 1 (July 20, 2018): 14-

http://www.stttorsina.ac.id/jurnal/ 31. Accessed October 15, 2020. index.php/epigraphe. 